УДК 314.7

\title{
Ethnic Enclaves as a Social and Territorial Phenomenon (Based on the City of Novosibirsk)
}

Svetlana A. Madiukova and Olga A. Persidskaia* Institute of Philosophy and Law of SB RAS 8 Nikolaev Str., Novosibirsk, 630090, Russia

Received 15.12.2016, received in revised form 27.06.2017, accepted 07.07.2017

The present research considers specificity of the relationship between migrants and the host community in a large city based on the example of Novosibirsk and illustrated with materials of popular and expert surveys conducted with the participation of the authors. Integration of migrants into the sociocultural space of the city is studied from the point of view of balance between the strategies of security and development, while the focus of the authors' attention is directed to the study of the processes of social and territorial exclusion of migrants from the urban environment and their self-organization in enclaves.

The dual nature of ethnic enclave formation is analysed: on the one hand, an enclave is formed as a result of pressure made by the host community, on the other hand, it implements the migrants' strategy of "easy adaptation". The enclave allows reproduction of the ethno-cultural system and the social structure of the "country of origin" in the new location. The dependence of the identification strategies of migrants on the influence of the host community is formulated: the ethno-cultural identity of migrants coming to Russia for short periods and settling in enclaves does not normally transform, while the ethno-cultural identity of migrants oriented to long-term or permanent residence is transformed in accordance with stereotyped images, existing in the mass consciousness of the host community.

The concept of "interstitial zones" is justified as actual for modern Russian sociology, as it adequately reflects the specifics of migrants' resettlement in enclaves in modern Russian cities.

In general, based on the analysis of empirical materials, it was concluded that, although enclaves are nominally present on the city map, there is no integration of the social system of the enclave with the city's network.

Keywords: migrants, host community, enclave, city, adaptation, expert survey, identity.

The present research was carried out within the framework of the project RFFI-OGON No. 16-03-00144 "Sociocultural monitoring of interethnic community: development and trial of indicator system in the activity of municipal administration bodies of the city of Novosibirsk" (supervised by Iu.V. Popkov).

DOI: 10.17516/1997-1370-0107.

Research area: social philosophy.

(C) Siberian Federal University. All rights reserved

* Corresponding author E-mail address: sveiv7@mail.ru; olga_alekseevna@mail.ru 
Introduction. The issue of interaction between migrants and the host population of the Russian cities has become extremely, or even excessively popular among modern researchers. The topicality of the issue is caused by currently existing practices: the majority of large modern Russian cities attract migrant workers, intensifying the migration flow and aggravating the issues of communications between migrants and local residents. We cannot but agree with V.I. Diatlov who wrote that "Russian history has never witnessed such enormous role of crossborder migration in the economic, demographic, cultural, ideological and political sense. Hot discussions in the community influence politics, civil disturbances sometimes grow into bashing; deliberate attention of mass media, though not distinctive, but deliberate lobbying, intensive regulatory, institutional and administrative activity of the state bodies of all possible levels manifest the great concern about the problem" (Diatlov, 2015: 198).

Empirical base of the research. The specificity of the relations between migrants and the host community of Novosibirsk is illustrated with the results of the popular and expert surveys carried out in the city in the years 2014 and 2016 correspondingly. The popular survey covering 573 people was carried out by the Institute of Philosophy and Law of the Siberian Branch of Russian Academy of Science, using purposive sampling. A series of expert surveys was carried out by sociologists from Novosibirsk State Technical University and the Institute of Philosophy and Law of the SB RAS in the year 2016 within the framework of the grant project RSSF No. 16-03-00144 "Sociocultural monitoring of interethnic community: development and trial of indicator system in the activity of municipal administration bodies of the city of Novosibirsk" (supervised by Iu.V. Popkov). Among the selected experts there were representatives of the scientific community having the experience of studying interethnic relations and migration processes along, as well as some specialists working at local administrations, social and cultural institutions of the city and the districts popular among ethnic communities and migrants. The present research is based on 15 interviews with experts. It is worth noticing that the present research project is still in process, and further presentation of the whole scope of opinions of the issue will be based on profound interviews and focus groups with the representatives of ethnic diasporas of Novosibirsk, as well as outputs of a repetitive popular survey scheduled for the year 2017 to illustrate the dynamics of the relationships between the host community and migrant workers.

\section{Migrants in the urban environment.}

Understanding a city as a sustainable and at the same time dynamic environment with its local peculiarities of interaction between migrants and locals is described in the previous article titled "Migrants in the social space of a city" (Madiukova, Persidskaia, 2016). It is important to understand, that even outside the migration problem research any city is a compound, sophisticated and a multi-dimensional phenomenon, encompassing processes of social and spatial segmentation and differentiation based on economic, cultural, social, ethnic and other features. And the migrants are trying (or not trying) to integrate into this internally compound environment. Besides the quantitative surplus of alien population, cities are going through the process of qualitative modification of their social and cultural characteristics. It is especially emphasized by I.M. Kuznetsov who says that the necessity for filling all working vacancies in certain branches of economy "is not a problem of simply mechanical surplus of some abstract labour force, but the population, maintaining and reproducing the social and cultural environment as a historically developed 
totality with an immanent level of economic potential (Kuznetsov, 2008: 274). It is not coincidence that V.I. Diatlov also remarks that the "migration issue" research formed a general field of issues: "its key component is the evaluation of opportunities and risks based on the contraversial integrity of two approaches, one related to security and the other to development... The followers of the development-related idea believe that cross-border migrants are absolutely essential, as without them it is impossible to keep the economy running and provide the modernization breakthrough. For this reason migration policy should be based on massive attraction of migrants, maximum legalization of migration, and all possible measures for social, economic and cultural integration of migrants into the host community. The followers of the security-centred approach see migrants as a hazard to the identity of the host community, its ethnocultural homogeneity and stability, a reason for inevitable destructive ethnical conflicts. The natural consequence of such opinion is the demand to restrict the migrant inflow and drive out the existing ones" (Diatlov, 2015: 199).

Thus, both researchers and administrative decision-makers regulating the "migrants issue" should consider the complexity and sophistication of the relationships between migrants and the host community, as well as the consequences of such relationships both for local urban communities and the all-Russian culture, economy and social life. The migration policy of a country should be based on economic and demographic reasonability, taking the antimigration movements into account.

Scientific discourse of the "migrant issue". We may now speak of a developed discourse, a system of categories used by the socio-humanitarian researchers: to refer to the process of accepting migrants into the host community such terms as adaptation, integration, accommodation, and acculturation are used. I.M. Kuznetsov focuses on distinguishing between two aspects of integration. "One of them is structural or institutional integration, i.e. measure of integration into the basic institutions of the society; the other one is cultural integration or acculturation, i.e. measure of integration into a new axiological and regulatory system and development of a new sociocultural identity" (Kuznetsov, 2008: 275).

Referring to the processes of social and territorial isolation of migrants, researchers normally operate the terms enclave, ghetto (ghetto may be forced (isolation by a dominating community) or voluntary, being a mechanism of self-isolation and conservation of a certain community), social and territorial localization, social and territorial exclusion, cluster, segregation, and the term "interstitial zones" adapted from American sociology.

The topic of interaction between migrants and the host community is complicated and multifaceted, and the phenomenon of enclave development is only one of its multiple aspects. The term of "enclave", originated from the Latin inclavatus "closed", initially refers to a part of a state's territory entirely surrounded by the territory of one other state. Currently this term is used in the field of ethnology. Most frequently an ethnic enclave is understood as a place of compact residence of one ethnos (ethnic group) surrounded with a territory habited by another ethnos (group of ethnoses). We understand ethnic enclave as ethnic localization of residents in the places of residence, labour etc. I.S. Andronov speaks of an enclave as "a state within a state": "in a city, an ethnic enclave follows its own rules, regulations and values, has its own internal market, ethnic businesses etc. Such situation opens the way to conflicts and high social tension" (Andronov, 2014: 57).

Dual nature of ethnic enclave formation.

On one hand, it is worth agreeing with V.I. 
Mukomel' and I.M. Kuznetsov that enclave development is a result of the policy selected by the host community. "It is not only about the everyday relations between the diaspora and the local community that are normally not so harmonic. A great value is gained by the duality of social, economic, and cultural institutions intended to assist socialization of the population. However, currently they are hardly focused on the socialization of migrants from other societies" (Kuznetsov, Mukomel', 2005: 34). In our opinion, in this context one of the key reasons for ethnic enclave formation is the growth of antimigrant sentiments in the host community. Its representatives are captured by popular stereotypes and prejudice, projecting them on all ethnic migrants "by default" (see more on migrants perception stereotypes formation: Madiukova, Persidskaia, 2015; Madiukova, 2016). In the interviews, speaking of the contacts between migrants and the host community, our experts remark the rarity of such encounters, their closed and hostile nature. "They are not willing to make contacts. These are closed groups living as enclaves... There is a big number of such isolated groups that do not wish to have any contacts with the host community... They live in a closed, reserved way, and their behaviour is not always friendly" (Interview with a researcher, No. 9), "They (migrants - authors) say that they go out and sometimes communicate with locals. But what do they mean by that... Let's say one of them goes shopping to buy some groceries, if he speaks a little bit of Russian he buys groceries for all the group, while others remain silent, helping" (Interview with a researcher, No. 11). It seems like it is the host community itself, guided by stereotypes, that is making the relationships negative: "The local population... sometimes wants to have their worst ideas proven" (Interview with a researcher, No. 13).
In her article "Concepts of functioning of migrant communities in American sociology" M.A. Safonova remarks that in cities migrants concentrate in the areas with cheaper rent, convenient communications with the closest industrial facility, and unattractive landscape. Frederic Thrasher called such areas interstitial zones of the city (Thrasher, 1968: 21-22). Expanding Thrasher's idea, M.A. Safonova explains that "in nature, alien communities tend to concentrate in clefts, cracks, ravines: fractures of any kind. Thrasher claims that similar fractures can be also found in social structure. $\mathrm{He}$ calls them "interstitial". These are natural zones located between two (or more) structured and sought for zones. They are of no interest for the economically successful and socially established population (they either have never been popular or got abandoned at a certain moment). The agents filling such zones are either newly arriving migrants or unsuccessful city dwellers. There face no counteraction from the locals as it could happen in the areas of traditional residence of the successful residents (Safonova, 2012: 110). This term seems to reflect the processes of migrants' residence in modern Russian cities, and for this reason it is also usable in modern Russian sociology: migrants prefer living either closer to their work places, or in deprived and cheap outskirts.

Based on the interview analysis we may conclude, that the expert community of Novosibirsk is inclined to state that the problem of ethnic enclaves is not acute in the city. The experts often applied the term "enclave" to the areas of concentrated residence of migrant workers perceived by the host community as aliens in the general ethnic picture of the city. Among such territories the experts mentioned markets and some outskirts, which, to our mind, can be explained by two factors: ethnic division of labour (migrant workers from the Caucasus 
and Central Asia are normally occupied in the fields of construction, service and trading at markets) and the cheap accommodation in the outskirts, despite the inaccessibility by public transport. The popular survey outlined such potentially conflict raising areas as markets, particularly, Khiloksky market and the market on Gusinobrodskoe highway in Oktyabrsky District, along with the adjacent housing estate on Vysotsky Street, housing estates in Rodniki and Snegiri neighbourhoods, and the outskirts of the city. Answering the question on which places in Novosibirsk could become or have already become seat grounds of aggression and interethnic tension, the respondents named Khiloksky (49 \%), Gusinobrodsky (48 \%), Levoberezhnyy (14\%) markets and the adjacent territories. Among problematic ones, multiethnic schools were also mentioned (Popkov et al., 2015: 160).

On the other hand, the process of enclave formation is caused byconscious selection of the "easiest" adaptation strategy due to the society's unpreparedness for integrating migrants into the local community. The reason for such strategy selection may be sophisticated bureaucracy of registration and obtaining work permission, bad knowledge of Russian language and law, understanding the receiving environment as hostile (not without reason). I.S. Andronov remarks, that "the prerequisites of ethnic enclaves bear not only ethnocultural, but also social character, caused by the need for help and security which is only possible in the company of compatriots" (Andronov, 2014: 57), and explains, that "the advantages of this strategy are clearly social and psychological: the support of compatriots, living in a microsociety preserving their regular norms of behaviour, life, daily routine, and the same time an opportunity of improving their wealth in comparison to what is available back in their homeland" (Andronov,
2014: 58). In this research, many respondents were also convinced that enclaves serve as a temporary and easier platform for adaptation of newcomers: "My additude to it (enclave formation - author) is negative. I think it is possible as a transitional stage when it helps people assimilate on a certain territory within a certain society. But living in such isolated communities and localities should be only temporary (Interview with a researcher, No. 2). "As for enclave formation, I believe, it is positive for the migrant workers... it is a nice and friendly get-together for them, a group even if it includes people of different nationalities... We have asked them if they had any conflicts there. They said they had a specific purpose, which is work; they said they lived in isolated places (corporate dormitories of factories, construction sites) and they did not really need conflicts, as the whole little community might suffer from it" (Interview with a researcher, No. 11).

\section{Ethnocultural identity of migrants and} its dependence on the migration purpose. In modern Russian cities the ethnocultural system and social structure of the "country of origin" is often reproduced in the new territory. The most relevant factor is the dependence of the identification strategies of the migrants themselves on the influence made by the host community. As I.M. Kuznetsov writes, the "quasi-reality" of a "Transcaucasian" happens to be the only niche in the urban social environment an Azerbaijani may turn to (in the researched case), if he wishes to become a local citizen, since the everyday urban life provides no other realities adequate to his self-consciousness. It is the wish to "live (and see the urban society "as everyone else" makes an Azerbaijani (or a representative of another non-local ethnic group in Moscow) consider himself ("as everyone else") to be more of a "Transcaucasian" than his compatriots not eager to integrate, less "Azerbaijani" (or even "Muslim") than them. This phenomenon of 
influence made by a local structure of common realities and senses may be called a forcedvoluntary segregation: no one forces these people to put on the "Transcaucasian" mask, but they are more likely to get recognized in the urban environment if they do, which is not compulsory for temporary migrant workers who are not planning to stay here and to assimilate. For this reason the latter persistently and stably refuse to mix the Caucasian nations, evidently different for them, and the corresponding ethnonyms into one category (Kuznetsov, 2008: 283-284). As G.S. Solodova remarks, that is the reason way "pendulum-like migration offers large opportunities for preserving the basic ethnocultural identity in the host community. Contacts with families in the homeland remain more intensive and relevant than in the event of final migration to another country. There is a sense of temporariness of the territorial location. Spiritual and communicative connection with the motherland remains strong, as a rule, it does not weaken or tear. Consequently, season migration is the least advantageous from the point of view of sociocultural integration into the host community. Interaction happens mostly within the ethnical group of the migrant workers; as a result, they are less motivated to learn Russian language and their acculturation is restricted. Similar constant rotation of migrant workers in Russia aids mutual cultural acquaintance and exchange, not expansion or transformation of the identity" (Solodova, 2015: 85). This way, the mechanism of the migrants' reproduction of their ethnocultural identity is inversely related to the degree of inclusion into the host community: the ethnocultural identity of the migrant workers coming to Russia for more or less short term is not likely to get transformed; at the same time, the ethnocultural identity of migrants aiming at long stay or even permanent residence in
Russia does transform in accordance with the stereotypes existing in the mass consciousness of the host community.

Enclave formation has its advantages for migrants, simplifying and minimizing their interaction with the host community. On the other hand, support of traditional structures and practices of "excluded" residence prevent socialization and adaptation in the urban environment, getting over the language barrier; migrants have no access to education, improvement of their professional qualification. Moreover, the "problem of such environment is the tendency of turning into a sustainable, successive and self-developing, quite corrupt shadow subculture with its own infrastructure including local citizens and officials of various levels, with possible connections to certain territories of the host community, i.e. into a conflictogenic multinational enclave within local environment" (Kuznetsov, Mukomel', 2005: 33).

Role of host community. We cannot ignore the fact that the host community itself is not homogenous, and its attitude to aliens may be also diverse. V.I. Diatlov writes that there is no single host community as such; there is a compound and controversial conglomerate of persons and their interests. At the same time, as we agree with V.I. Diatlov again, the observed and often forced migrant-phobia may become (or is already becoming) one of the most relevant mechanisms of consolidation of Russian society and even the fundament of the modern stage of nation-building (Diatlov, 2015: 199). At that, if we take the host community in the simplest way as a single organism, it becomes evident that the absence of integration and incorporation of migrants causes changes of the sociocultural portrait of such society, leading to "cultural opposition" of the host community as the one willing to preserve its cultural succession and its established sociocultural identity (Solodova, Palopezhentseva, 2013: 79). 
A bright example of inhomogeneity of the host community is the fact that the experts have different opinions on whether cultural enclaves do or do not exist in Novosibirsk. Some of them believe that strictly speaking there are no settlements of ethnic migrants in the form of enclaves: "Of course, I may be mistaken and there may be someone who could convince me, but I feel no enclaves in the city" (Interview with a researcher, No. 5); "Thanks god, there are no enclaves as such in our urban environment. We do not have any homogenous quarters or residential estates where only migrants lived and locals did not" (Interview with a researcher, No. 1); "I don't feel it in Akademgorodok" (Interview with a researcher, No. 8). However, there is a group of experts who recognize a certain tendency to enclave formation in the city: "I would agree they exist in residence estates" (Interview with a researcher, No. 8); "There are districts where the proportion of people with foreign traditions and appearance is really high. Though there is no distinctive domination, different groups are represented in certain proportions" (Interview with a researcher, No. 1).

"Migrant problem" rhetoric. In the present context the rhetoric of the "migrant problem" is also relevant. The experts accept that the migrant community is inhomogeneous itself, and it would be wrong to speak of migrants as of an integrated group with common objectives, regulations and behaviour practices. Researchers of migrant problems normally differentiate between forced and voluntary migrants, migrants from different countries, coming from urban or rural environment, from various ethnic and/or confessional groups, social strata etc. I.S. Andronov rightfully remarks that "the inhomogeneity of migrants as a social group is caused bydifferences in their countries of origin, national and cultural background, as well as individual peculiarities of their migration experience. Internal structure and organization of ethnic diasporas and enclaves assumes existence of subgroups different from each other in the level of income, specificity of social and legal status, relations with the authorities, locals and employers, where higher positions are occupied by ethnic representatives who, due to their individual migration experience, can serve as social adaptation agents for their compatriots (Andronov, 2014: 59). This inhomogeneity is also noticed by the experts; answering a question on the tendency to enclave formation, one of them remarked: "Is there such a tendency? Or are we speaking of migrant workers as such? Because if we take a general look at representatives of other ethnoses, they are diffusively distributed. Our neighbours are Korean, German, there are some distant successors of the Chinese... And if you are asking of migrant workers, then it is quite obvious, why... They do not really settle down here, they rather come here to work for a while and then leave again" (Interview with a researcher, No. 13). Along with that, the "common point" in the "migrant" rhetoric isunderstanding "migrants" as temporary migrant workers. Moreover, we agree with I.M. Kuznetsov who wrote, that "the lifestyle of temporary migrant workers, i.e. the least integrated and the least motivated to integrate foreign migrant group (irrespective of certain ethnic origins), is the basis for construction and maintenance of a stereotype of a "Transcaucasian" ("Asian") person, who is, actually, an aggressive alien bearing vague features of "foreign" origin applicable to any ethnic group. This image is extrapolated on all the groups anthropologically or culturally different from the common urban population, which includes both ethnic groups belonging to the indigenous citizens of Russia and representatives of ethnic diasporas who have been living in Russia for centuries" (Kuznetsov, 2008: 283). It is important to understand the 
reason of the enclave-forming strategy outlined by G.S. Solodova: "it is hard to be adoptive and educable, especially in mature age. Acquisition and operation of new regulations is often associated with simultaneous re-education, reorientation and replacement of some values and views (when all the vacancies are full), acquired and approved at the previous stages of life. From this point of view the migrants' desire to preserve their habitual lifestyle is easy to explain and does not always mean any negative attitude to the host culture. It is more comfortable and simple to behave the way you know, the way your relatives behave, the way your nation has lived for ages. At that, the efficiency of new, often repeated socialization is lower the more internalized than the ideas and practices of the original culture" (Solodova, 2011: 45). The point of view expressed by one of the experts in our research is of great interest: he suggested that the enclave strategy of adaptation is more common for people of mature age. "Perhaps, this (enclave formation - authors) is more typical of the people of the age when you have certain mindsets. You must preserve these mindsets to keep on living. There is no other way of surviving in a different place. An elderly woman can remain spiritually and psychologically comfortable only in a closed environment. The same is for her elder children. But youngsters and teenagers easily become citizens of the world" (Interview with a researcher, No. 4).

The classification suggested by I.M. Kuznetsov seems to be one of the most comprehensive ones: it divides migrants into two groups, permanent residents and temporary migrant workers: "The migrants oriented at permanent residence and, therefore, at integration with the host community, tend to recognize the priority of social and cultural values and norms of the host environment in comparison with the medium of their origin; temporary migrant workers consider the host environment as an economic and technological resource" (Kuznetsov, 2008: 277-278). An illustrative result of the research carried out by I.M. Kuznetsov is the answer to the question "If you had a choice, how would you prefer to live in Moscow?" Among my compatriots $25.4 \%$ (oriented at permanent residence) / $56.5 \%$ (temporary migrant workers); Among local residents $52.6 \%$ (oriented at permanent residence) / $36.1 \%$ (temporary migrant workers), which demonstrates that the tendency to enclave formation is typical, first of all, for temporary migrant workers. Later, having achieved some economic and/or social success, such people strive to escape the "ethnic ghetto" and become a "local".

Factors and prerequisites for enclave formation. There is a series of factors playing the key role in forming areas of concentrated residence of migrants. For instance, many researchers mention language barrier, misunderstanding of national customs and mismatch of axiological and mental mindsets that cause negative attitude to migrants in the host society (Andronov, 2014: 57). At that, each and every settlement demonstrates its own features: on one hand, it is caused by geographic peculiarities (climate, terrain etc.) and on the other, by the uniqueness of sociocultural organization of the local people (Karanov, 2013: 25). In their interviews, the experts remarked some common social tendencies connected to the specificity of interaction between the host community and migrants in the globalizing society context: "Without cultural borders a multicultural society just cannot exist" (Interview with a researcher, No. 1); "When students come, they live as an enclave a priori, for they need to hold on to each other in a foreign country and a foreign society" (Interview with a researcher, No. 5). Moreover, the experts revealed some circumstances that underlie the formation of problematic zones in Russia and Novosibirsk in particular. First of all, it is the factor of "pressure" 
from Russian host community: "Russians dominate here, and since the collapse of the USSR they feel vulnerable, convinced that at home they are the ones to establish the order of socialization and relationships common in the society. On the other hand, if these orders and regulations happen to be impossible to follow for the diasporas, these groups become less open, they isolate, creating the conditions for enclave formation" (Interview with a researcher, No. 1). The second is the cultural specificity of composition and accommodation of the migrants' flow: "they (enclaves - authors) were created in the 1990-s and the early 2000 $\mathrm{s}$, when families migrated and settled next to each other (Interview with a specialist, No. 5). Representatives of the host community also speak of migrants as of a marginal, or even a criminal community: "they position themselves as "aliens", which never feels nice, for this reason we feel like isolating ourselves or isolating them, so that the "clustering ones" do not make present a threat... That is why this tendency is not very good... It makes me think of horrible things: when they are concentrated in one place, they are easier to isolate. But when they are all together, they look dangerous, for sure. When you come to realize that when one nation comes into a cluster, and it is a foreign nation, and it is the reason for it to create a cluster, they are likely to hide something dangerous, and it is definitely not a neighbourhood where you would go" (Interview with a researcher, No. 13); "They will exist in a closed, isolated way. We are aware of the Muslim factor, of the extremist one. It may explode" (Interview with a researcher, No. 7); "Enclaves occur only in the places with a criminal element" (Interview with a specialist, No. 5).

Ethnic enclaves in the city of Novosibirsk. Generally, speaking of enclaves, the experts remarked it this or that way that the social system of the enclave is not united with the urban system, or, in other words, "they are adjusted to local life, but not integrated into the culture" (Interview with a researcher, No. 3). Similar processes were noticed by G.S. Solodova and M.S. Palopezhentseva, speaking of isolation of migrants as a consequence of their social deprivation causing the aggravation of their social exclusion and association based on their own social, cultural and confessional norms, not those of the host society (Solodova, Palopezhentseva, 2013: 78).

Generally, according to the experts, enclave formation in Novosibirsk is not a relevant problem, and, strictly speaking, there are no enclaves as such in current map of Novosibirsk. The areas that tend to become enclaves are just territories of concentration of migrant workers, close to large markets and in the outskirts. This population is not included in the social network of the city. For this reason, they cause development of various opinions of themselves, including some scary ones.

Conclusion. Measures of overcoming the enclave formation problem in the city of Novosibirsk. Among the measures the experts see as useful for smoothening the enclave formation problem are: creation of special institutions and platforms for cultural and intercultural events: "We need a House of Friendship or a resource centre, where they could come together and solve their problems; there should be a channel for them to make their voice heard and make influence on the social environment" (Interview with a researcher, No. 1). According to the experts, the optimal strategy of interethnic relations development is involvement of migrants into various national-cultural associations and administrative bodies: "Charity communities, religious organizations, ethnic organizations have always existed not only in Russia, but in the whole world" (Interview with a researcher, No. 9); "It needs involvement of the civil society, and the state needs to form the conditions for all the 
ethnic groups to be represented in consultative bodies" (Interview with a researcher, No. 1). Moreover, the experts expressed opinion of the necessity for common pragmatic objectives and for understanding interethnic communication in the context of cultural exchange and enrichment, no matter what ethnicities are in focus: "generally speaking, why would the Azerbaijani House cooperate with the Jewish Cultural Centre? Just to exchange cultures? If there is no interest, it will never happen. Take Odessa around 50 years ago, when it was home for Ukrainians, Jews, Greeks, Turks, Bulgars... So many nations got intertwined in that city, and they just could not but interact. There were so many of them, each having their own culture, but they contacted... If there is no pragmatic objective, I would not get into contact with a foreign culture. Again, I could assume that, as a perfect scenario, the guys who come here need to have a pragmatic objective to make contacts with the Russian-speaking population of Novosibirsk, because again, they need to assimilate to settle here" (Interview with a researcher, No. 14). The experts believe that an essential component of efficient interethnic policy is the monitoring of their condition, along with interaction of the administrative officials with the research community: "I don't know whether our regional government has any scientific consultant who could monitor their resolutions or present the results of interethnic relations analysis carried out in our city to the government, but it would be nice if there was one. If there is, it may prevent many problems occurring at the administration level" (Interview with a researcher, No. 13). The experts see the efficiency of "deliberate development of positive cultural and informational background in the areas where the development of "ethnic enclaves" has already begun" (Interview with a specialist, No. 6).

To conclude, we would like to mention the optimistic fact that some experts really suggest that the problem of ethnic enclave formation in Russia will not be acute in the future either, for Russia is a multinational country and its citizens have historically developed some practices of peaceful interethnic communication: "I may be wrong, but in Europe the idea of mixing the ethnicities has not been planted on time. They let those enclaves appear. While here we have historically been mixed" (Interview with a specialist, No. 9).

The present research was carried out within the framework of the project RFFI-OGON No. 16-03-00144 "Sociocultural monitoring of interethnic community: development and trial of indicator system in the activity of municipal administration bodies of the city of Novosibirsk" (supervised by Iu.V. Popkov).

\section{References}

Andronov, I.S. (2014). Vneshnie migranty v sotsial'noy strukture naseleniia megapolisa [External migrants in the social structure of megalopolis population], In Sociology and Law, 1(23), 55-60.

Diatlov, V.I. (2015). Migranty: problemy bezopasnosti i razvitiia dlia Rossii (mnogoobrazie i konflikt grupp interesov $\mathrm{v}$ prinimaiushchem obshchestve) [Migrants: problems of security and development for Russia (diversity and conflict of interest groups in the host society)]. Chelovek $v$ meniaiushchemsia mire. Problemy identichnosti $i$ sotsial'noy adaptatsii $v$ istorii i sovremennosti [A person in the changing world. Problems of identity and social adaptation in history and modernity], 198-209.

Popkov, Iu.V., Tiugashev, E.A., Erokhina, E.A., Madiukova, S.A., Persidskaia, O.A., Goncharova, G.S., Markhinin, V.V., Udalova, I.V., Kostiuk, V.G. (2015). Etnosotsial'nye protsessy $i$ 
ehtnonatsional'naia politika $v$ regionakh Sibiri [Ethnosocial processes and ethno-national policy in the regions of Siberia]. Novosibirsk, SB RAS Publ., 273 p.

Karanov, D.P. (2013). Migranty i prinimayushchee obshchestvo: kul'turnyy aspekt mezhehtnicheskikh otnosheniy $\mathrm{v}$ gorodskoy srede [Migrants and host society: the cultural aspect of interethnic relations in the urban environment], In Politia, 1, 24-35.

Kuznetsov, I.M. (2008). Migranty v megapolise i provintsii: variativnost' realizatsii integratsionnogo potentsiala [Migrants in the megalopolis and provinces: the variability of the implementation of the integration potential]. Rossiya reformiruiushchaiasia [Reforming Russia]. Ed. M.K. Gorshkov. Vol. 7. Moscow, Institute of Sociology RAS, 273-288.

Kuznetsov, I.M., Mukomel', V.I. (2005). Adaptatsionnye vozmozhnosti i setevye sviazi migrantskikh ehtnicheskikh men'shinstv [Adaptive opportunities and network connections of migrant ethnic minorities]. Moscow, Institute of Sociology RAS, 51 p.

Madiukova, S.A. (2016). Stereotipy i zabluzhdeniia v vospriiatii migrantov prinimaiushchim soobshchestvom [Stereotypes and misconceptions in the perception of migrants by the host community], In Russia - the Space of the Dialogue of Peoples: Proceedings of the All-Russian Scientific and Practical Conference. Novosibirsk, NSU, 112 p., 47.

Madiukova, S.A., Persidskaia, O.A. (2016). Migranty v sotsial'nom prostranstve goroda [Migrants in the social space of a city], In Siberian Philosophical Journal, 12 (1), 161-176.

Madiukova, S.A., Persidskaia, O.A. (2015). Sub'ektivnye i ob'ektivnye aspekty vospriiatiia migrantov $\mathrm{v}$ massovom soznanii prinimaiushchego soobshchestva (na primere g. Novosibirska) [Subjective and objective aspects of the perception of migrants in the mass consciousness of the host community (on the example of Novosibirsk)], In Siberian Philosophical Journal, 13 (4), 112-119.

Safonova, M.A. (2012). Kontseptsii funktsionirovaniia migrantskikh soobshchestv v amerikanskoy sotsiologii [Concepts of the functioning of migrant communities in American sociology], In Sociological research, 5, 106-117.

Solodova, G.S. (2011). Integratsiya migrantov-musul'man v rossiyskoe obshchestvo [Integration of Muslim migrants into Russian society], In Sociological research, 4, 44-49.

Solodova, G.S. (2015). Faktory podderzhaniia ehtnokul'turnoy identichnosti migrantov [Factors supporting the ethnic and cultural identity of migrants], In Siberian Philosophical Journal, 13 (2), 83-88.

Solodova, G.S., Palopezhentseva, M.S. (2013). Kul'turnoe soprotivlenie ili kul'turnaya integratsiya? [Cultural resistance or cultural integration?], In Siberian Philosophical Journal, 11 (4), 74-79.

Thrasher, F.M. (1968). The Gang. A Study of 1.313 Gangs in Chicago. Chicago and London, The University of Chicago Press, 628 p. 


\title{
Этнические анклавы
}

\section{как социально-территориальный феномен (на примере г. Новосибирска)}

\author{
С.А. Мадюкова, О.А. Персидская \\ Институт философии и права СО РАН \\ Россия, 630090, Новосибирск, ул. Николаева, 8
}

Специифика взаимоотношений мигрантов и принимающего сообщества в крупном городе рассмотрена на примере Новосибирска и проиллюстрирована материалами массового и экспертного опросов, проведенных при участии авторов. Интеграция мигрантов в социокультурное пространство города рассмотрена с точки зрения баланса между стратегиями безопасности и развития, при этом фокус внимания авторов направлен на исследование процессов социильно-территориального исключения мигрантов из городской средьл и их самоорганизации в анклавах.

Рассмотрена двойственная природа формирования этнического анклава - с одной сторонь, анклав формируется как результат воздействия принимающего сообщества, с другой стороныl, в нем реализуется стратегия адаптации самих мигрантов «по легкому пути». Анклав позволяет локально воспроизводить этнокультурную систему и социальную структуру «странь исхода» на новой территории. Зафиксирована зависимость идентификационных стратегий мигрантов от влияния принимающего сообщества: этнокультурная идентичность мигрантов, приезжающих в Россию на короткий срок и селящихся в анклавах, минимально подвергается трансформации, в то время как этнокультурная идентичность мигрантов, ориентированных на долгосрочное или постоянное проживание, трансформируется в соответствии со стереотипными образами, сущзествующими в массовом сознании принимающего сообщества. Понятие «интерстециальные зоны» обосновано в качестве актуального для современной отечественной социологии, так как адекватно отражает специфику процессов анклавного расселения мигрантов в современных российских городах.

В иелом, на основе анализа эмпирических материалов сделано заключение о том, что при номинальном присутствии на карте города, объединение социильной системь анклава с сетью города отсутствует.

Ключевые слова: мигранты, принимающее сообщество, анклав, город, адаптаџия, экспертньй опрос, идентичность.

Настоящее исследование проводилось в рамках проекта RFFI-OGON № 16-03-00144 «Cоциокультурный мониторинг межэтнического сообщества: разработка и испытание индикаторной системы в деятельности органов муниципального управления города Новосибирска» (контролируется Ю. В. Попков).

Научная специальность: 09.00.11 - социальная философия. 